\title{
PROSES MERANTAU PEREMPUAN MINANG DI JAKARTA
}

\author{
Process of Minang's Women Migration in Jakarta
}

\author{
Sinta Oktavia*), Titik Sumarti, dan Nurmala K Pandjaitan \\ Departemen Sains Komunikasi dan Pengembangan Masyarakat, Fakultas Ekologi Manusia, IPB \\ *Email: sintaoktavia@ymail.com
}

\begin{abstract}
The purposes of this study were to analyze the migration process of Minang's women. The study show that (1) since 1980 Minang's women tend to migrate in direct way to the destination area which they have choose and in the case of Minang's women in Jakarta it's mean that they went to Jakarta directly, while transit trend in the other destination area seldom practiced. The trend of direct migration pattern to Jakarta also supported by the improvement of the transportations facilities. Along with it, women migration flow becomes more open since the Minang's women migration was chain migration based on kinship who have migrate first (2)Although Minang women migrant have stay in destination area for 5 (five) years or more, they keep coming back to their origin area even once in a while.
\end{abstract}

Keywords: minang's women migrants, pattern and flow of migration

\begin{abstract}
ABSTRAK
Tujuan dari penelitian ini adalah untuk menganalisis proses migrasi perempuan Minang. Penelitian menunjukkan bahwa (1) sejak tahun 1980 perempuan Minang cenderung untuk bermigrasi dengan cara langsung ke daerah tujuan yang mereka pilih dan dalam kasus perempuan Minang di Jakarta berarti bahwa mereka pergi ke Jakarta secara langsung, sementara tren transit di tujuan lain daerah jarang dipraktekkan. Kecenderungan pola migrasi langsung ke Jakarta juga didukung oleh peningkatan fasilitas transportasi. Seiring dengan itu, aliran migrasi perempuan menjadi lebih terbuka karena migrasi perempuan Minang adalah migrasi rantai berdasarkan kekerabatan yang bermigrasi (2) Meskipun perempuan Minang migran telah tinggal di daerah tujuan selama 5 (lima) tahun atau lebih, mereka tetap datang kembali ke daerah asal sesekali.
\end{abstract}

Kata kunci: pola dan arus migrasi, wanita Minang migran

\section{PENDAHULUAN}

\section{Latar Belakang}

Migrasi merupakan perpindahan tempat tinggal secara permanen atau relatif permanen (untuk jangka waktu minimal tertentu) dan jarak minimal tertentu (Rusli, 2012). Migrasi di luar negri menurut Goldscheider (1985) dipengaruhi oleh beberapa kondisi, seperti perpindahan yang diakibatkan perkawinan, perceraian (keretakan perkawinan), perubahan siklus kehidupan, serta perpindahan yang diakibatkan oleh pola karir atau pekerjaan. Goldscheider (1985) mengemukakan bahwa migrasi di luar negri, seperti Chili, India dan beberapa bagian Afrika (negara berkembang), pola migrasi yang dominan adalah migrasi antar wilayah perkotaan dan antar wilayah pedesaan. Migran perkotaan dari beberapa daerah Afrika menurut Goldscheider (1985) dalam proses migrasinya akan kembali bertempat tinggal di daerah asal, dan menjalani sebagian besar dari kehidupan di daerah asal. Migran asal Amerika Serikat yang bermigrasi ke Italia atau ke Puerto Rico menurut Goldscheider (1985) sedikit berbeda, mereka hanya sebagian kecil yang kembali atau bahkan ada yang tidak kembali.

Setiap daerah punya proses migrasi yang berbeda karena pengaruh budaya tidak bisa diabaikan, antara migrasi di suatu negara dengan migrasi di negara lain, antara migrasi perempuan dengan migrasi laki-laki, yang dalam kajiannya sering dipisahkan analisanya. Salah satu tipe migrasi yang cukup khas di Indonesia adalah merantau. Merantau seperti halnya konsep migrasi, berhubungan dengan keluarnya penduduk dari suatu desa (Hugo 1981; Naim 1984), ditambahkan oleh Naim (1981) yakni dengan maksud kembali pulang dan atas kemauan sendiri.

Perempuan punya keunikan proses migrasi tersendiri, salah satunya karena perempuan tidak sebebas laki-laki dalam melakukan perpindahan. Kajian migrasi perempuan Indonesia telah banyak dilakukan, namun masih fokus pada migrasi internasional terhadap perempuan Indonesia yang bekerja di Luar negeri. Kajian migrasi internal terhadap perempuan di Indonesia masih terbatas, terutama terhadap perempuan dari suatu daerah tertentu. Kajian migrasi perempuan kebanyakan masih fokus pada migrasi perempuan secara keseluruhan, seperti kajian Wiyono (2003) dan Bandiyono (2006) terhadap migran perempuan di Indonesia secara keseluruhan, Mursini et al. (2009) terhadap migran perempuan di Batam, dan Budiyanto (2010) terhadap migran perempuan di Lampung.

Setiap daerah di Indonesia yang masih kental budayanya, 
punya batasan tersendiri terhadap perempuannya, sehingga kajian yang konsen terhadap migran perempuan dari daerah (etnis) harusnya banyak dilakukan. Kajian yang fokus terhadap perempuan dari suatu daerah dan etnis tertentu masih terbatas, dua kajian yang ditemukan seperti yang dilakukan Pandjaitan (1990) terhadap migran asal desa Purwaraja Jawa Barat di Lampung dan Rianty et al. (2004) terhadap perempuan asal desa Ujung Alang Jawa Tengah.

Berbicara soal keterbatasan perempuan melakukan perpindahan, adat Minangkabau mengenal "sumbang perjalanan" sebagai salah satu perbuatan sumbang bagi perempuan (salah) yang harus dihindari perempuan Minang (Hakimy 2004). Perempuan Minang dengan demikian harusnya lebih terbatas untuk keluar dari daerah asal dibandingkan perempuan dari daerah lainnya, karena bukan hanya sebatas kekhawatiran orang tua seperti yang dialami perempuan asal desa Purwaraja dalam kajian Pandjaitan (1990).

Kajian mengenai proses migrasi perempuan Minang dengan demikian relevan dan penting dilakukan, yang sejauh ini baru fokus pada laki-laki Minang atau perantau Minang secara keseluruhan, seperti yang dilakukan Naim (1984) tentang perantauan laki-laki Minang dan Bandiyono (2006) tentang migrasi di Indonesia secara umum dan menemukan bahwa etnis Minang sebagai salah satu etnis yang tinggi tingkat mobilitasnya. Mursini et al. (2009) memang membahas tentang migran perempuan Minang yang lebih banyak dibandingkan etnis lainnya di Batam, namun masih membahas migran perempuan secara keseluruhan di Batam bukan fokus pada perempuan Minang. Ditemukannya perempuan Minang oleh Mursini et al. (2009) paling banyak di Batam pun masih tergolong wajar, karena Batam secara jarak masih dekat dengan Padang, terutama pada tahun tersebut fasilitas transportasi juga sudah berkembang.

Menariknya adalah, Zoelverdi (1995) sebelum tahun 1980 telah menemukan perempuan Minang yang tinggal di Jakarta, artinya Jakarta telah menjadi daerah tujuan rantau yang cukup diminati, namun masih sedikit karena Jakarta masih menjadi rantau elit masa itu. Kasus perantau perempuan Minang yang disampaikan Zoelverdi (1995) pun secara keseluruhan adalah mereka yang berasal dari keluarga dengan kedudukan ekonomi tinggi (orangtua mereka rata-rata pejabat pemerintah). Selain itu, Zoelverdi (1995) juga baru sebatas mengemukakan kasus mengenai anak dari perantau Minang yang telah sukses di rantau, dan dan di antara mereka pun hanya sebagian kecil ditemukan benar-benar meninggalkan daerah asal, sebaliknya mereka yang telah lahir di rantau.

Lalu bagaimana dengan proses merantau perempuan Minang setelah tahun 1980, mengingat Jakarta telah menjadi rantau untuk semua orang (bukan lagi rantau elit). Selain itu, sarana transportasi juga telah semakin berkembang. Orang Minang sebelum sarana jalan, transportasi, dan komunikasi selancar dan semaju sekarang, telah banyak yang pergi merantau sebagaimana yang dipaparkan Naim (1984), bagaimana pula pada masa sekarang dengan semakin berkembangnya sarana transportasi modern (seperti pesawat), tentu arus migrasi semakin terbuka dengan pola merantau yang juga semakin berkembang.
Masalah penelitian pertama secara spesifik adalah, bagaimana pola merantau perempuan Minang terutama setelah tahun 1980 dan hal apa saja yang mempengaruhi perkembangan pola merantau, serta bagaimana pula kaitannya dengan arus merantau perempuan Minang tersebut. Bagaimana pola tinggal (menetap) nya perempuan Minang di daerah tujuan rantau, menjadi masalah penelitian selanjutnya. Hal ini mengingat apa yang disampaikan Naim (1984) bahwa orang Minang merantau tanpa meninggalkan struktur sosialnya, ada orang tua, saudara, dan kerabat yang masih tinggal di daerah asal.

\section{METODE PENELITIAN}

Penelitian ini dilaksanakan di Jakarta, terutama di Jakarta Pusat dan Jakarta Selatan. Populasi sampling dalam penelitian ini adalah perantau perempuan Minang yang memang meninggalkan daerah asalnya di tanah Minangkabau (terlepas dari apapun alasan mereka meninggalkan daerah asalnya) dan disaat dilakukannya penelitian mereka ditemukan tinggal di Jakarta, karena penelitian ini melihat bagaimana pola merantau dari perempuan Minang yang tinggal di Jakarta. Responden dipilih secara purposive sampling yakni sebanyak 60 orang. Mengacu pada konsep penggolongan migrasi Goldscheider (1985), pola merantaunya Naim (1984) serta penelitian terdahulu, analisis data sebagai berikut pada Tabel 1.

\section{Tabel 1. Analisis Data Penelitian}

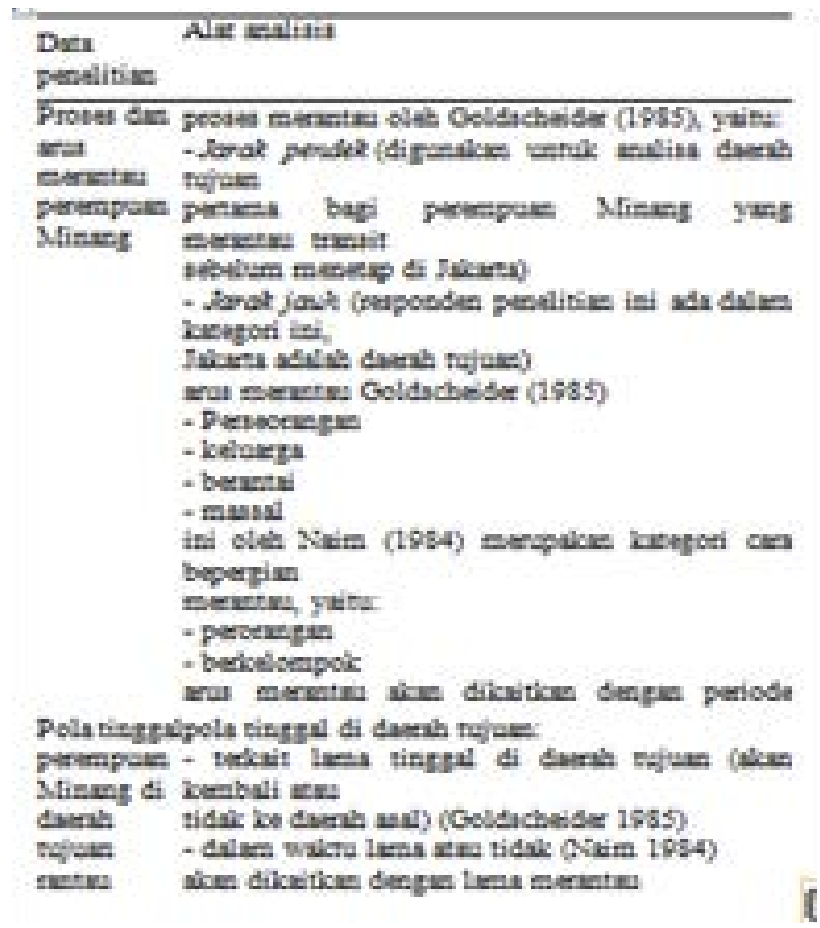

\section{HASIL DAN PEMBAHASAN}

\section{Pola Merantau Perempuan Minang}

Pola merantau adalah proses merantau yang dilakukan minimal oleh dua orang responden, karena pola merupakan sesuatu yang berulang-ulang dilakukan (telah dilakukan 
lebih dari satu orang responden). Pola merantau tersebut terdiri atas: (1) pola merantau A (transit kabupaten atau kota dalam satu provinsi); (2) pola merantau B (transit provinsi dalam satu pulau); (3) pola merantau C (transit daerah Jawa non Jakarta); (4) pola merantau D (transit kabupaten/kota dalam satu provinsi ditambah dengan transit daerah Jawa non Jakarta); (5) pola merantau E (langsung ke Jakarta); dan (6) lain-lain proses merantau yang belum terpola (yaitu transit provinsi dalam satu pulau ditambah transit daerah Jawa non Jakarta, dan transit antar pulau non Jawa). Tabel 4 menunjukkan bahwa sebagian besar responden melakukan pola merantau D.

Berangkat dari konsep migrasinya Goldscheider (1985), perempuan Minang yang melakukan perpindahan lokal (migrasi internal) cenderung melakukan migrasi jarak jauh (antar provinsi dalam satu pulau, bahkan antar pulau). Pola merantaunya perempuan Minang lebih beragam dibandingkan pola merantaunya perempuan Jawa yang cenderung langsung ke satu daerah tujuan rantau, seperti yang disampaikan oleh Pandjaitan (1990) bahwa perempuan asal Purwaraja Jawa Barat yang merantau ke Lampung memang dari awal merantau telah menjadikan Lampung sebagai daerah tujuan pertama. Perempuan asal desa Ujung Alang Jawa Tengah juga demikian, yakni langsung ke satu daerah tujuan rantau yang dinilai mampu memberikan peluang kerja, seperti yang disampaikan Rianty et al. (2004). Lalu bagaimana jika dihubungkan dengan periode merantau, karena kajian terhadap perempuan Jawa tersebut juga berada pada tahun yang berbeda. Berikut akan dijelaskan lebih jauh mengenai pola merantau perempuan Minang berdasarkan periode merantau.

\section{Hal-hal yang Berhubungan dengan Pola Merantau Responden}

\section{Hubungan Pola Merantau dengan Karakteristik Responden}

\section{Hubungan Pola Merantau dengan Periode Merantau}

Pola merantau tidaklah seragam, akan ada perbedaan dari waktu ke waktu. Pola merantau responden berhubungan signifikan dengan periode merantau.

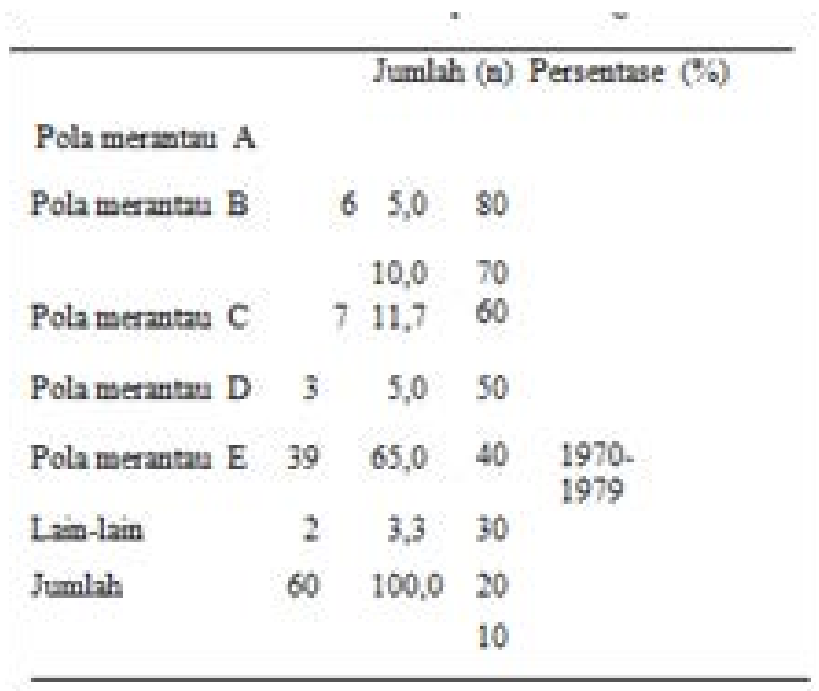

Gambar 1. Pola Merantau Perempuan Minang
Gambar 1 menunjukkan bahwa responden cenderung melakukan pola merantau E sejak tahun 1980, terlihat dari garis warna merah, hijau, dan ungu yang mewakili periode merantau responden sejak periode 80 -an hingga periode 2000 -an yang terlihat melonjak pada pola merantau E.

Garis warna biru yang mewakili pola merantau responden sepanjang periode 70 -an yang melonjak pada pola merantau B, menandakan bahwa periode 70-an perempuan Minang masih banyak yang menjadikan daerah sekitar Sumatera (seperti Pekanbaru dan Lampung) sebagai daerah tujuan rantau utama. Transit di daerah Pekanbaru terutama hingga sekarang masih ada, namun tidak sebanyak pada periode 70 -an. Periode 80-an bahkan tidak ada responden yang merantau dengan pola merantau $\mathrm{B}$ sebaliknya responden cenderung melakukan pola merantau Aselain pola merantau E. Daerah tujuan rantau yang pertama dituju pada periode 80-an bukan lagi menjadi daerah tujuan utama, sebaliknya hanya sebagai batu loncatan untuk menuju daerah rantau yang lebih jauh, tidak seperti halnya mereka yang merantau periode 70 -an.

Perempuan Minang memang telah memiliki kecendrungan menuju ke satu daerah tujuan rantau yang menjadi pilihan terutama sejak periode 80 -an, namun sepanjang periode merantau merantau transit di daerah lain tetap ada. Perempuan pola merantaunya masih beragam hingga sekarang, dan berarti memang berbeda dengan pola merantau perempuan asal Purwaraja yang dikemukakan Pandjaitan (1990) dan perempuan asal Ujung Alang yang dikemukakan Ryanti et al. (2004).

Semakin lancarnya transportasi (terutama transportasi udara) juga menjadi pertimbangan dalam analisa ini. Hasil analisis data menunjukkan bahwa periode merantau berhubungan signifikan dengan alat transportasi yang digunakan. Semenjak tahun 2000 transportasi pesawat cenderung digunakan, seiring dengan itu pola merantau E pun semakin berkembang. Kelancaran transportasi dengan demikian ikut menentukan pola merantau. Gambar 2 menunjukkan bahwa garis merah yang mewakili perkembangan penggunaant ransportasi pesawat memperlihatkan bahwa tren penggunaan pesawat dimulai sejak periode 90-an, dan semakin berkembang pada periode 2000-an. Tren penggunaan bus (menggunakan jalur laut) yang diwakili garis warna biru telah tren pada periode 80-an dan masih digunakan hinggasekarang (masih diminati).

Tren penggunaan bus sempat menurun pada periode 80 an karena pada periode tersebut awal berkembangnya penggunaan kendaraan pribadi untuk merantau. Penggunaan kendaraan pribadi hingga sekarang semakin berkembang, meskipun tidak sebanyak penggunaan pesawat dan bus. Aktifitas bepergian untuk jarak yang jauh menjadi lebih efektif dari segi waktu dengan berkembangnya sarana transportasi pesawat. Perempuan Minang tidak lagi harus bermalam di jalan yang oleh adat dinilai sumbang (salah), dan mereka tidak lagi ragu untuk bepergian ke daerah yang jaraknya jauh. Waktu untuk bepergian dari Padang ke Jakarta saja telah dapat ditempuh dalam waktu kurang lebih 1,5 jam. Sesuai dengan yang dikemukakan Goldscheider (1995) dan Naim (1984), maka dengan semakin berkembangnya sarana transportasi maka hambatan terkait "jarak" dalam melakukan perpindahan telah teratasi. 


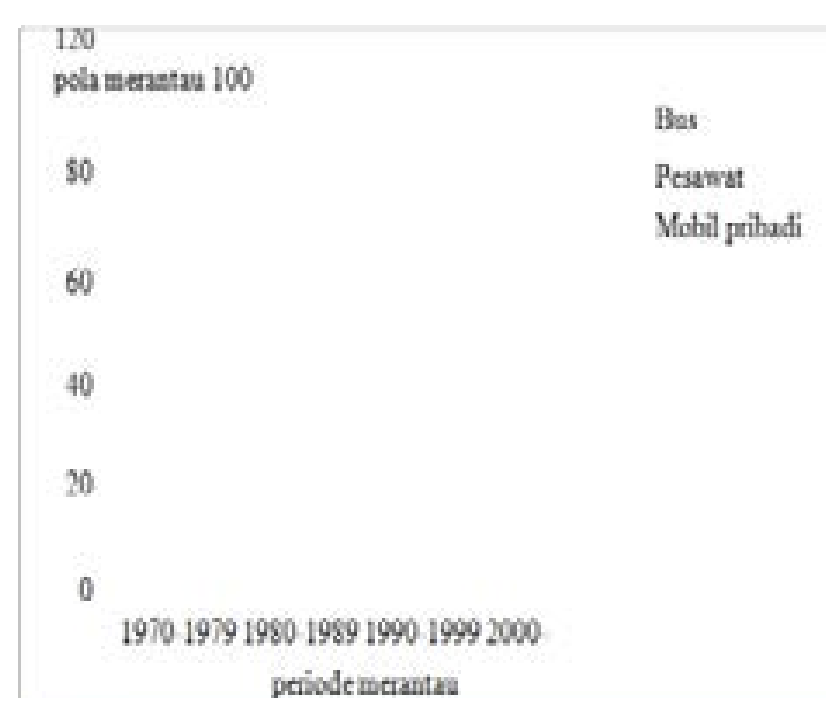

Gambar 2. Persentase hubungan antara perkembangan alat transportasi yang digunakan responden dengan periode merantau

\section{Hubungan Pola Merantau dengan Umur Responden ketika Meninggalkan Daerah Asal}

Umur migran yang berpengaruh terhadap migrasi di luar negeri menurut Goldscheider (1985), tidak berpengaruh signifikan bagi kasus merantaunya perempuan Minang. Berdasarkan analisis data, hubungan antara umur dan pola merantau tidak signifikan (yaitu jarak bepergian merantau tidak berhubungan signifikan dengan umur responden tersebut). Informasi tersebut bagaimanapun tetap menunjukkan kecenderungan pola merantau responden berdasarkan umur. Gambar 3 menunjukkan bahwa responden yang yang berumur 15-24 tahun lah yang cenderung tingkat merantaunya tinggi. Grafik warna merah yang menunjukkan persentase hubungan umur responden (15-24 tahun) dengan pola merantau yang ada disetiap pola merantau sekligus menunjukkan bahwa responden yang berumur 15-24 tahun juga lah yang pola merantaunya paling beragam, disusul setelahnya responden yang meninggalkan daerah asal saat berumur di bawah 15 tahun (ditunjukkan grafik berwarna biru). Responden yang umurnya telah mencapai 35 tahun serta diatas 35 tahun secara keseluruhan langsung menuju ke satu daerah tujuan rantau utama, yakni merantau pola E.

Responden yang meninggalkan daerah asal saat masih berumur di bawah 15 tahun secara keseluruhan karena dibawa merantau oleh keluarga atau kerabat, yang nantinya akan dibahas lebih jauh terkait ikatan keluarga atau kerabat yang tinggal di rantau. Responden yang merantau umur $25-34$, khususnya yang merantau pola $\mathrm{C}$ rata-rata dikarenakan alasan pekerjaan (panggilan kerja), serta ada juga yang dikarenakan keberadaan orang yang di kenal di daerah tujuan rantau.

Reponden merantau yang lebih muda cenderung merantau karena alasan pendidikan, pekerjaan serta karena keberadaan keluarga yang telah lebih dulu merantau. Responden yang telah menempuh pendidikan tinggi cenderung memutuskan merantau ke Jakarta untuk bekerja, dan cenderung transit dulu di daerah sekitar kabupaten atau kota (umumnya di Padang) atau transit daerah Jawa non Jakarta (umumnya di Depok dan di Bandung) untuk melanjutkan pendidikan. Responden yang berumur 35 tahun ke atas umumnya merantau karena alasan ekonomi (memulai usaha baru), namun secara keseluruhan juga punya keluarga yang telah lebih dulu merantau yang menawarkan untuk berusaha di rantau.

$$
\begin{aligned}
& 120 \\
& 100 \\
& 80 \\
& \text { umur }<15 \text { tahun } 60 \\
& \text { umur } 15.24 \text { tahunumur } 25.34 \text { tahun } 40
\end{aligned}
$$$$
\text { umur } \geq 35 \operatorname{tahun} 20
$$

\section{$\begin{array}{llllll}0 & \text { A } & \text { B } & \text { C } & \text { D } & \text { Elaim-lain }\end{array}$}

Gambar 3. Persentase hubungan pola merantau dan umur responden

Perempuan Minang yang merantau sebagian besar adalah yang berusia dibawah 35 tahun. Hal ini sebagaimana yang dikemukakan Goldscheider (1985) bahwa setiap orang punya tingkat mobilitas yang berbeda, yakni kaum muda lebih cenderung berpindah daripada orang-orang yang sudah tua. Goldscheider (1985) menambahkan bahwa orang yang memiliki pekerjaan tertentu dan dengan pendidikan tertentu juga memiliki selektivitas berpindah yang berbeda.

\section{Hubungan Pola Merantau dengan Status Pernikahan Responden ketika Meninggalkan Daerah Asal}

Hasil analisis data menunjukkan bahwa antara status perkawinan dengan pola merantau tidak berhubungan signifikan, namun tetap memperlihatkan kecenderungan merantau antara responden yang merantau dalam status belum menikah dengan responden yang berstatus menikah. Gambar 4 menunjukkan bahwa responden yang saat memutuskan merantau telah berstatus menikah cenderung menuju ke satu daerah tujuan rantau dan menetap di sana (yaitu pola merantau E).

Responden yang sempat transit di satu atau beberapa daerah tujuan rantau (pola merantau diluar pola merantau E) secara keseluruhan adalah mereka yang berstatus belum menikah saat meninggalkan daerah asal. Responden yang berstatus belum menikah tersebut, yaitu: (1) responden yang merantau karena alasan pendidikan (menempuh pendidikan di daerah lain); (2) responden pola merantau yang punya keluarga atau kerabat yang telah tinggal di rantau (non Jakarta), singgah dulu disana; (3) responden yang mendapat panggilan kerja di daerah non Jakarta (umumnya Tangerang), bekerja disana sebelum akhirnya pindah dan bekerja di Jakarta.

Responden yang berstatus menikah cenderung merantau jarak jauh (langsung ke Jakarta mengikuti suami), dan 
tidak ada yang transit di daerah rantau lain yang jaraknya lebih dekat. Responden yang merantau dalam kondisi telah menikah sebagian besar memang belum memiliki anak, karena setelah menikah mereka langsung berangkat dengan suami ke rantau. Status pernikahan dan jumlah anak tidak berpengaruh pada daerah tujuan rantau yang dituju. Tiga kasus ditemukan merantau sekeluarga (beserta suami dan anak-anak). Kasus pertama merantau sekeluarga dengan membawa delapan orang anaknya ke Jakarta untuk memulai usaha baru (periode 70-an). Kasus berikutnya juga sama yakni merantau sekeluarga untuk memulai usaha di Jakarta dengan membawa 3 (tiga) orang anak. Kasus terakhir merantau sekeluarga dengan membawa 2 (dua) orang anaknya untuk menghilangkan trauma anak-anaknya dari gempa dan berakhir menetap.

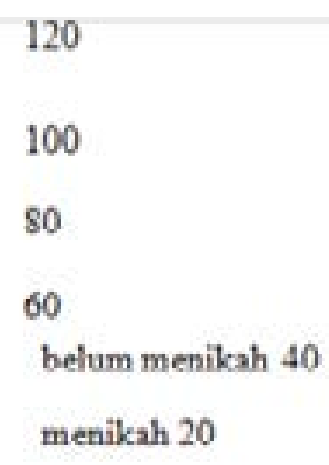

A

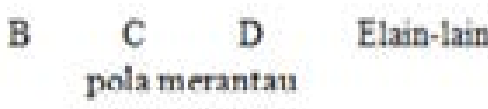

Gambar 4. Persentase hubungan antara pola merantau dan status pernikahan ketika awal memutuskan merantau

Status pernikahan dan jumlah anak yang sangat berpengaruh terhadap daerah tujuan migrasi yang dituju oleh perempuan asal desa Purwaraja Jawa Barat (Pandjaitan, 1990), ternyata tidak berlaku untuk kasus merantaunya perempuan Minang.

\section{Hubungan Pola Merantau dan Perubahan Siklus Hidup}

\section{Hubungan Perluasan Keluarga dan Pola Merantau}

Responden sebagian besar punya keluarga (kerabat) yang tinggal di rantau. Pola merantau memang tidak berhubungan signifikan dengan ada tidaknya ikatan keluarga keluarga atau kerabat di daerah tujuan rantau, namun cukup menunjukkan adanya kecenderungan dari masing-masingnya.

Gambar 5 menunjukkan bahwa yang memiliki keluarga atau kerabat di daerah rantau adalah yang paling banyak melakukan pola merantau E (langsung merantau jarak jauh). Keberadaaan keluarga atau kerabat di daerah tujuan rantau juga yang membuat terbentuk proses merantau lain-lain. Salah satu kasus merantau lain-lain adalah bu ASD (26) yang sempat pergi ke tempat kakaknya di Batam untuk jalan-jalan sembari menunggu panggilan kerja dari Jakarta.

Gambar 5. Persentase hubungan antara pola merantau dan keberadaan keluarga (kerabat) di rantau. Semakin banyaknya keluarga atau kerabatan yang tinggal di rantau telah membuka arus migrasi dan membentuk pola merantau tersendiri. Responden sebagian besar merantau ikut keluarga atau kerabat yang telah lama tinggal di rantau. Responden cenderung menuju daerah rantau dimana keluarga atau kerabatnya tinggal.

$\begin{array}{ll}70 & \\ 60 & \text { tidak ada keluarga } \\ 50 & \text { (kerabat) yang } \\ 40 & \text { tinggal di daerah } \\ 30 & \text { tujuan } \\ 20 & \text { ada keluarga } \\ 10 & \text { (kerabat) yang } \\ & \text { tinggal di daerah } \\ & \text { tujuan }\end{array}$

Gambar 5. Persentase hubungan antara pola merantau dan keberadaan keluarga (kerabat) di rantau

Responden yang orang tuanya memutuskan merantau secara keseluruhan akan ikut ke daerah tujuan rantau orang tuanya. Kasus merantau bu RM (40 tahun, dibawa orang tuanya ke Jakarta setelah tamat SMA, dan karena dapat suami yang juga berusaha di Jakarta akhirnya menetap di Jakarta. Kondisi lain seperti kasus merantaunya bu YL (17 tahun), ikut temannya ke Bogor setelah tamat SMP karena orang tua (ibu) menikah lagi dengan orang Bogor setelah bercerai dengan ayahnya, dan sekarang tinggal serta bekerja di Jakarta.

Daerah tujuan rantau perempuan asal Purwaraja yang sangat ditentukan oleh keberadaan keluarga (kerabat) di sana (Pandjaitan, 1990), kenyataannya tidak berpengaruh signifikan bagi perantauan perempuan Minang. Perempuan Minang memang cenderung menuju daerah dimana ada keluarga atau kerabat yang tinggal disana, disamping daerah tersebut memang daerah yang diminati untuk ditu. Semakin banyaknya keluarga (kerabat) yang tinggal di kota yang disebut Goldscheider (1985) sebagai perluasan keluarga, ikut menentukan pola merantaunya perempuan Minang.

\section{Hubungan Pembentuan Keluarga dan Pola Merantau}

Terbentuknya keluarga inti (perubahan status pernikahan dari belum menikah menjadi menikah) ikut menentukan pola merantau perempuan Minang. Responden yang merantau pola E sebanyak 4 (empat) kasus merantau setelah menikah dengan laki-laki Minang yang telah lama tinggal dan berusaha di rantau, salah satu contoh adalah kasus merantaunya bu AN. Bu AN (54 tahun), ikut suami ke Jakarta setelah menikah (saat berumur 20 tahun) karena suami telah tinggal dan berusaha di Jakarta. Responden yang sebelumnya sempat transit di daerah lain dan pindah ke Jakarta karena menikah dengan laki-laki Minang yang telah tinggal dan bekerja di Jakarta, jugaditemukan sebanyak 4 (empat) kasus. Ini menunjukkan bahwa pada kondisi tertentu pembentukan keluarga inti (perubahan status) dapat membuat seseorang meninggalkan 
daerah asalnya (meninggalkan daerah tujuan rantau sebelumnya). Hal tersebut dikarenakan setelah menikah perempuan Minang akan mengikuti suaminya dimanapun suaminya tinggal.

Apa yang dikemukakan Goldscheider (1985) bahwa terbentuknya keluarga baru dapat menentukan proses merantau, memang ditemukan pada kasus perantauan perempuan Minang. Perubahan status perkawinan yang dapat mengubah tempat tinggal seorang perempuan Minang adalah perkawinan yang terjadi antara perempuan Minang dengan orang rantau (laki-laki Minang yang telah lama merantau).

\section{Hubungan Pengurangan Keluarga dan Pola Merantau}

Berkurangnya anggota keluarga juga dapat menyebabkan merantaunya seorang perempuan Minang. Ada dua responden yang dibawa oleh keluarga atau kerabatnya karena orang tuanya meninggal, dan bu AS adalah salah satu contoh kasus. Bu AS (41 tahun), dibawa mamak (paman) nya merantau sejak umur 6 tahun dan disekolahkan hingga SMP. Bu AS ikut ke daerah manapun mamaknya merantau, hingga sempat tinggal di Pekanbaru. Ketika mamaknya merantau ke Jakarta, bu AS juga dibawa oleh mamaknya. Selama ikut dengan mamaknya bu AS membantu mamaknya di usaha rumah makan mamaknya, hingga bakat tersebut menurun ke bu AS, dan setelah menikah bu AS pun membuka rumah makan sendiri. Orang Minang memiliki hubungan kekerabatan yang masih tinggi atau masih berfungsinya peran mamak (yakni mamak punya tanggungjawab terhadap kemenekannya). Ini menunjukkan bahwa pengurangan anggota keluarga (biasanya orang tua) bisa saja mengubah tempat tinggal seseorang.

\section{Kesempatan Ekonomi dan Pola Merantau}

Kesempatan ekonomi di suatu daerah tertentu akan menjadi penentu lain bagi berpindahnya seseorang dari daerah asal menuju daerah yang menyediakan kesempatan ekonomi tersebut. Responden dalam penelitian ini yang ditemukan merantau karena kesempatan ekonomi ada tiga kondisi, yaitu: (1) karena panggilan kerja, (2) karena tawaran kerja, dan (3) karena kesempatan usaha. Bu BDA (26 tahun) berpendidikan S-1, merantau ke Jawa karena memperoleh panggilan kerja dari salah satu perusahaan swasta di Tangerang. Bu BDA sekarang tinggal dan bekerja di Jakarta setelah keluar dari tempat bekerja sebelumnya. Bu AF (32) berpendidikan SMA merantau ke Jakarta karena mendapat tawaran bekerja di toko kakaknya di Jakarta. Bu HN (61 tahun) merantau sekeluarga karena kesempatan usaha yang lebih besar di Jakarta, disamping adanya kerabat yang tinggal di Jakarta.

Perempuan Minang merantaubukan hanyauntuk menanggapi kesempatan ekonomi, namun juga dikarenakan perubahan siklus hidup. Adapun responden yang merantau karena alasan ekonomi cenderung menuju daerah yang memang menjanjikan secara ekonomi. Responden yang merantau karena alasan ekonomi sebagain besar merantau pola $\mathrm{E}$ (langsung ke Jakarta), artinya Jakarta menjanjikan secara ekonomi bagi orang Minang.

\section{Arus Merantau Perempuan Minang}

Hasil analisis data menunjukkan bahwa cara awal bepergian merantau responden berhubungan signifikan dengan periode merantau.

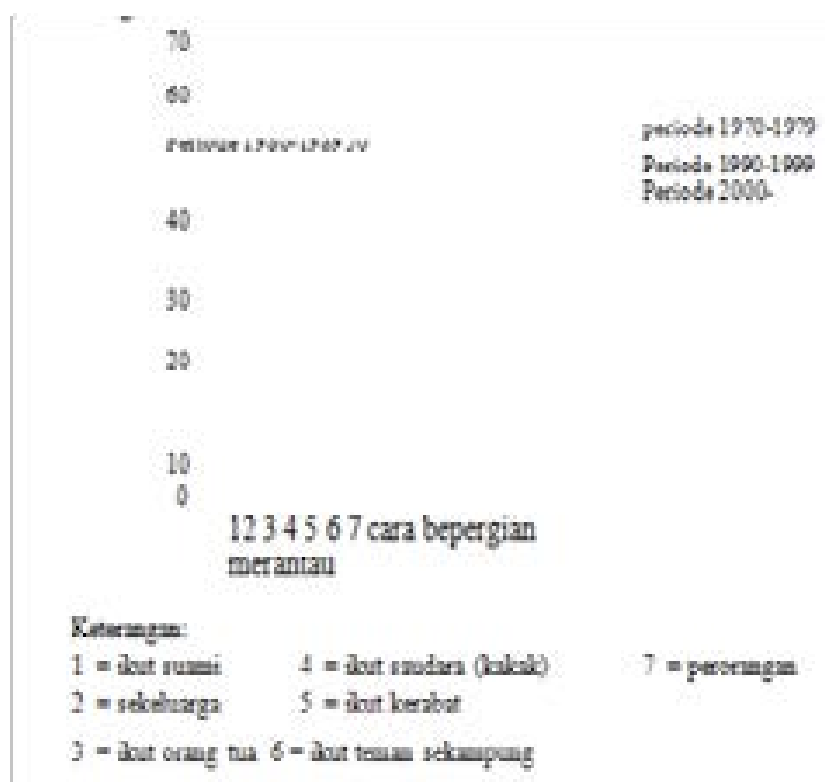

Gambar 6. Persentase hubungan cara bepergian merantau responden dengan periode merantau

Gambar 6 menunjukkan bahwa pada periode 70-an responden sebagian besar merantau untuk mendampingi suami yang merupakan laki-laki Minang yang telah lama tinggal dan bekerja (berusaha) di rantau. Tren merantau untuk mendampingi suami ini hingga periode 80 -an masih berkembang, mulai menurunnya adalah sejak tahun 90 -an hingga tahun 2000an. Seiring menurun merantau ikut suami, cara merantau lainnya pun mulai berkembang. Tren merantau periode 2000-an adalah merantau perseorangan, sementara cara merantau lainnya masih ditemukan namuntidak sebanyak merantau perseorangan. Sepanjang periode 90 -an responden justru cenderung merantau dengan ikut keluarga (saudara atau kakak) atau kerabat. Ini menandakan bahwa saudara atau kerabat tersebut adalah pembuka arus migrasi bagi responden yang merantau dengan cara tersebut. Responden yang sempat singgah di daerah lain umumnya ke Jakarta karena mendampingi suami atau secara perorangan. Mereka yang merantau perseorangan dari daerah tujuan rantau sebelumnya, umumnya menjadikan daerah rantau sebelumnya sebagai batu loncatan (pengalaman) untuk menuju rantau yang lebih jauh.

Seiring berkembangnya merantau perseorangan, merantau untuk mendampingi suami juga semakin berkurang sebagaimana yang telah dikemukakan sebelumnya. Ini menandakan bahwa arus migrasi perempuan Minang semakin besar, karena laki-laki Minang tidak lagi harus menjemput jodohnya ke daerah asal yang setelah menikah dibawa bersama merantau. Sekarang mereka (laki-laki Minang dan perempuan Minang) bertemu di rantau (ditandai dengan sebagian besar responden yang awalnya berstatus belum menikah akhirnya menikah dengan perantau laki-laki Minang). Tren perkawinan sesama perantau (orang rantau) yang semakin berkembang, membuat arus migrasi perempuan Minang juga semakin meningkat. Kondisi ini jika digambarkan menjadi semacam "tarik menarik", keinginan menikah dengan 
sesama orang Minang adalah magnetnya. Jika kondisinya adalah pada periode 70 -an atau 80 -an, masa itu medan magnetnya masih berpusat di daerah asal, sehingga lakilaki akan mencari jodoh di daerah asal, dan setelah menikah akan membawa istrinya ikut merantau, sehingga wajar pada masa tersebut responden cukup banyak yang merantau dengan pola merantau E (karena laki-laki Minang sebagian besar telah merantau ke Jakarta untuk berdagang). Periode berikutnya medan magnet mulai mendekat bahkan sangat dekat (prinsip magnet semakin dekat semakin kuat tarikannya), sehingga wajar jika lakilaki Minang yang telah tinggal di rantau kemudian lebih memilih yang telah tinggal di rantau (kondisi ini masih alami terjadi).

Magnet yang masih berpusat di daerah asal (jauh, daya tariknya tidak lagi kuat) pun akhirnya mulai berinisiatif untuk merantau, sehingga responden yang merantau periode 2000-an mengaku akan menetap di rantau jika bertemu jodoh orang rantau. Ini menandakan bahwa dari awal ada harapan untuk menikah dengan orang rantau. Kondisi terakhir ini lah yang cenderung mengarah pada kasus migrasinya perempuan asal desa Purwaraja Jawa Barat sebagaimana yang dikemukakan Pandjaitan (1990) bahwa mereka merantau ke Lampung untuk mencari jodoh karena laki-laki dari sana sebagian besar telah tinggal dan bekerja di Lampung. Perempuan Minang dalam merantau melibatkan proses sosial yang berbeda dengan perpindahan yang dilakukan laki-laki Minang. Perempuan Minang dalam perpindahan ditemukan menyertai orang tua, keluarga atau kerabat, menyertai suami serta ada juga yang menyertai teman dekat sekampung, hanya sebagian kecil yang memang melakukan perpindahan sendiri-sendiri (bertualang sendiri). Laki-laki Minang sendiri cenderung melakukan petualangan (perpindahan) sendiri-sendiri dan hanya sebagian kecil yang melakukan perpindahan menyertai orang lain (berkelompok), sebagaimana yang telah dikemukakan Naim (1984).

Perempuan Minang menuju suatu daerah tujuan rantau tertentu umumnya karena daerah tersebut mungkin untuk dituju, misalnya karena ada keluarga atau kerabat serta minimal ada teman dekat yang dikenal di daerah tujuan rantau tersebut. Ini sejalan dengan yang dikemukakan Goldscheider (1985) bahwa suatu daerah dituju karena memang pilihan jatuh pada daerah tersebut atau karena daerah tersebut mungkin untuk dituju. Damsar (1997) juga mengemukakan bahwa suatu daerah dituju oleh migran karena ketersediaan ikatan keluarga (kekerabatan) atau teman akrab (persahabatan) di daerah tersebut. Suatu daerah dituju oleh perempuan Minang juga dikarenakan pilihan memang jatuh pada daerah tersebut (seperti: karena kampus pavorit ada di daerah tersebut, atau peluang kerja yang diinginkan ada disana), dan kondisi ini jugalah yang cenderung membuat perempuan Minang merantau secara sendiri (berpetualang sendiri). Hal ini seiring dengan yang diungkapkan Goldscheider (1985) bahwa migran yang melakukan petualangan secara individu, proses sosialnya berbeda dengan migran yang dalam perpindahannya menyertai orang lain.

Responden awal merantau banyak yang melibatkan individu (ikut kakak atau kerabat), namun kemudian pun mampu mendatangkan keluarganya, sanak saudara atau teman dekat satu daerah asal dengan mereka. Kasus bu AY (37 tahun), merantau setelah menyelesaikan pendidikannya di SMA. Bu AY merantau ikut kerabatnya yang telah lama tinggal di Jakarta, dan setelah sukses di rantau mengajak kerabatnya untuk juga merantau ke Jakarta. Berkembangnya suatu arus migrasi ke suatu daerah tertentu akan membentuk pola merantau yang sama setelahnya. Responden yang merantau karena dibawa atau ikut atau bersama keluarga atau kerabat sebagian besar akan ikut orang yang membawa atau bersama siapa mereka pergi merantau. Pola merantau yang terbentuk adalah mengikuti pola merantau orang yang membawa atau orang yang diikuti.

Merantaunya orang Minang sebagian besar hasil dari "migran berantai" sebagaimana yang dikemukakan Goldsceider (1985), bahwa migrasi berantai adalah kondisi dimana migrasi yang pada mulanya hanya melibatkan seorang individu namun setelahnya akan mendatangkan anggota keluarga yang lain (sanak saudara atau masyarakat sekeliling tempat tinggal di daerah asal). Uniknya pada kasus perantauan perempuan Minang, apapun cara merantau mereka sebagian besar telah membuka arus migrasi, meskipun bukanlah arus massal seperti imigrasi ke Amerika Serikat awal abad ke sembilan belas. Arus migrasi massal hanya terjadi pada laki-laki Minang akibat PRRI sekitar tahun 1963, dan sebagian besar dari mereka adalah pemuda yang belum menikah, hanya sebagian kecil yang berstatus menikah (masa ini perempuan merantau karena mendampingi suami).

\section{Pola Tinggal Perantau Perempuan Minang di Daerah Tujuan Rantau}

Berbicara proses merantau maka juga harus mengkaji mengenai seberapa lama mereka menetap di daerah tujuan dan apakah mereka suatu waktu akan kembali ke daerah asal atau sebaliknya tidak pernah lagi kembali. Gambar 7 menunjukkan hubungan antara lama merantau dengan intensitas kembali ke daerah asal.

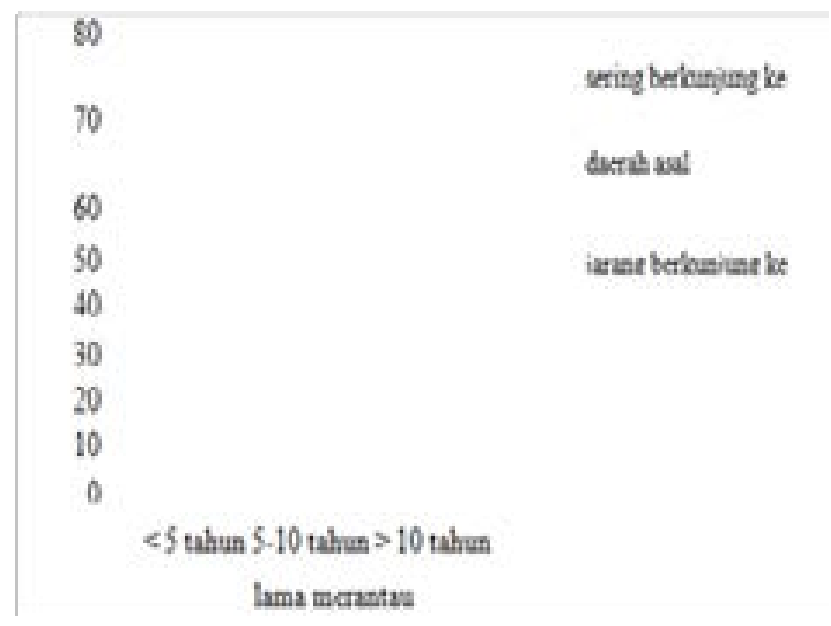

Gambar 7. Persentase hubungan lama merantau dengan intensitas kembali ke daerah asal Telah Menetap di Daerah Tujuan Rantau Tapi
Masih Sering Berkunjung ke Daerah Asal

Responden yang telah menetap di daerah tujuan rantau terutama yang telah merantau 5 (lima) tahun ke atas, seringnya mereka pulang ke daerah asal ditandai dengan kepulangan minimal sekali setiap tahun (setiap lebaran, 
baik ketika lebaran idul fitri atau ketika lebaran haji).

Bu AY (37 tahun), tamatan SMA, telah tinggal di Jakarta selama kurang lebih 17 tahun, semenjak merantau bu AY selalu menyempatkan pulang ke daerah asal untuk bertemu dengan orang tua dan saudara serta kerabatnya.

\section{Telah Menetap di Daerah Tujuan Rantau dan Jarang Kembali ke Daerah Asal}

Responden yang telah menetap ini ada juga yang mengaku jarang bisa kembali ke daerah asal, ditandai dengan hanya sesekali pulang ke daerah asal. Bu HN (61 tahun), tamatan SMA, telah tinggal di Jakarta selama 27 tahun dan mengaku bahwa semenjak merantau baru beberapa kali pulang ke daerah asal yakni ketika ada acara keluarga di daerah asal, karena sehari-harinya sibuk di pasar, lagi pula orang tua yang menjadi tujuan utama pulang kampung sudah tidak almarhum, keluarga yang lain pun sudah sebagian besar di rantau.

\section{Telah Menetap di Daerah Tujuan dan Belum Pernah Kembali ke Daerah Asal}

Responden yang karena telah menetap di rantau ini juga ada yang tidak lagi pernah kembali ke daerah asal semenjak merantau, seperti pada kasus merantaunya $\mathrm{Bu}$ ERZ. Bu ERZ (30 tahun), tamatan Perguruan Tinggi di salah satu universitas di Bandung, belum perah kembali ke daerah asal setelah 17 tahun tinggal di pulau Jawa. Bu ERZ mengaku tidak ada lagi keluarga yang harus dikunjungi di daerah asal karena seluruh keluarganya (orang tua dan saudaranya) telah tinggal di rantau. Contoh kasus lain yang juga belum pernah pulang ke daerah asal karena baru saja tinggal di Jakarta (kurang dari 2 tahun) namun ada rencana suatu saat kembali dan tinggal serta berusaha di daerah asal yaitu kasus merantaunya bu SFH (20 tahun). Responden yang punya rencana untuk kembali dan tinggal di daerah asal juga ada yang mengaku bahwa akan kembali jika tidak bisa lagi memperoleh penghasilan di kota; namun yang belum menikah umumnya mengaku akan menetap di rantau jika bertemu jodoh di rantau. Secara keseluruhan responden telah menetap di daerah tujuan, sementara kepulangan ke daerah asal umumnya kekerabatan di daerah asal tetap terjaga.

Mengacu pada konsepnya Naim (1984) ini termasuk kategori merantau dalam waktu yang lama, namun masih menyempatkan kembali ke daerah asal; sementara jika berangkat dari konsep pola tinggal Goldsceider (1985) maka secara tempat tinggal mereka tidak kembali lagi ke daerah asal (terutama yang telah memiliki rumah di Jakarta). Ini berbeda untuk kasus migrasi di luar negri sekaligus berbeda dengan kasus merantau perempuan asal desa Purwaraja yang disampaikan oleh Pandjaitan (1990) yang akan benar-benar kembali dan tinggal di daerah asal setelah 3 (tiga) hingga 4 (empat) tahun di rantau dan beralih pada aktifitas ekonomi di daerah asal, mereka tidak menetap di daerah tujuan rantau. Hal ini juga berbeda dengan kasus migran asal desa Ujung Alang Jawa Barat yang punya kecenderungan kembali ke daerah jika dijemput orang tua dan tunangannya, perantau perempuan Minang sebaliknya justru bertemu jodoh di rantau dan beberapa ada yang membawa orang tuanya tinggal di rantau.

\section{KESIMPULAN}

Perempuan Minang merantau dengan beragam pola merantau berdasarkan daerah tujuan rantau yang mereka tuju. Beragamnya pola merantau tersebut ditentukan oleh periode kapan mereka merantau. Setiap periode merantau punya kecenderungan pola merantau tersendiri, yaitu: (1) periode sebelum tahun 1980 (1970-1979) masih cenderung dengan pola merantau $\mathrm{B}$, sementara periode 1980 hingga sekarang sudah cenderung dengan pola merantau E. Jakarta telah menjadi daerah tujuan rantau yang sangat diminati. Arus merantau perempuan Minang periode 1970 hingga sekarang adalah merantau berantai.

Asalkan ada satu saja keluarga yang tinggal di rantau, anggota keluarga yang lainnya akan cenderung mengikut kemudian. Salah satu penanda berkembangnya arus migrasi berantai adalah dengan semakin banyaknya perempuan Minang yang merantau ikut keluarga atau kerabat yang telah lebih dulu merantau, yakni sejak periode 1990 hingga sekarang. Selain itu, sejak tahun 2000 hingga sekarang, merantau dengan cara ikut teman dekat satu kampung pun mulai berkembang. Ini menandakan bahwa arus merantau perempuan Minang akan semakin berkembang.

Perempuan Minang sebagian besar masih menyempatkan berkunjung ke daerah asal, jika tidak sering (ketika lebaran), minimal sesekali ketika ada acara keluarga di kampung. Ini menandakan bahwa perempuan Minang masih menjaga hubungan dengan daerah asal meskipun telah tinggal jauh dari daerah asal.

\section{DAFTAR PUSTAKA}

Bandiyono S. 2008. Relevansi karya penelitian migrasi dalam pembangunan. Jurnal Kependudukan Indonesia. 3(1): 21-36.

Budijanto. 2011. Faktor-faktor yang berpengaruh terhadap pengambilan keputusan wanita migran bermigrasi ke kota Malang. Jurnal Forum Geografi. 13 (24).

Damsar. 1997. Sosiologi Ekonomi. Jakarta (ID): PT RajaGrafindo Persada.

Goldsceider C. 1985. Populasi, Modernisasi, dan Struktur Sosial. Sumanto NB, Achiyat, Ala AB, Usman AG, Ratnawati, penerjemah. Jakarta (ID): CV. Rajawali Pr. Terjemahan dari: Population, odernization, and Social Structure.

Hakimy I. 2004. Pegangan Penghulu, Bundo Kanduang, dan Pidato Alua Pasambahan Adat di Minangkabau. Bandung (ID): PT Remaja Rosdakarya.

Hugo G. 1981. Population Mobility in West Java Yogyakarta (ID): Gadjah Mada University Press

Mursini, Jalil A, Murad A. 2009. Migrasi perempuan ke Kota Batam, Provinsi Kepulauan Riau. Jurnal Industri dan Perkotaan . 13(24): 155-178.

Naim M. 1984. Merantau Pola Migrasi Suku Minangkabau. Yogyakarta (ID): Gadja Mada University Press. 
Pandjaitan NK. 1990. Gerak penduduk wanita pedesaan pada komunitas pertanian lahan kering (Kasus sebuah dusun di Desa Purwaraja, Kecamatan Raja Desa, Kecamatan Ciamis-Jawa Barat) [Tesis]. Bogor (ID): Institut Pertanian Bogor.

Rianty A, Atmosudiro S, Gandarsih T. 2004. Merantau sebagai refleksi ideologi gender pada masyarakat Motean, Desa Ujungalang, Kecamatan Kampung Laut, Kabupaten Cilacap, Jawa Tengah (merantau as a reflection of gender ideology in Motean society, Ujungalang village). Jurnal Humanika. 17(4): 537555.

Rusli S. 2012. Pengantar Ilmu Kependudukan. Jakarta (ID): LP3ES.

Wiyono NH. 2000. Efek jenis migrasi pada status sosial ekonomi perempuan Indonesia: penerapan Two-Part Model [tesis]. Depok (ID): Universitas Indonesia

Zoelverdi E, editor. 1995. Siapa Mengapa Sejumlah Orang Minang. Jakarta (ID): BK3AM. 